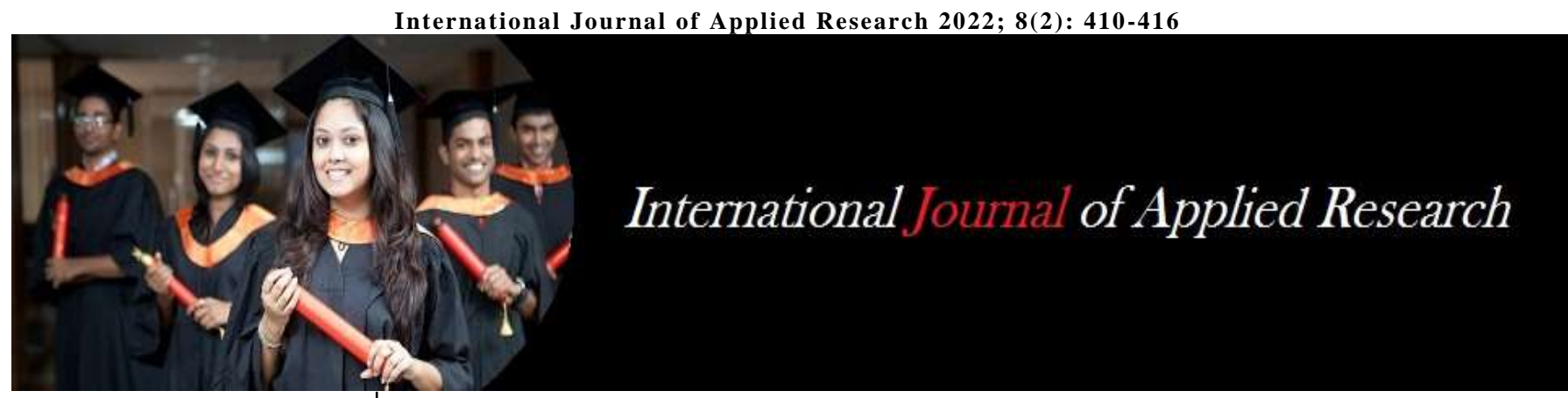

ISSN Print: 2394-7500 ISSN Online: 2394-5869 Impact Factor: 8.4 IJAR 2022; 8(2): 410-416 www.allresearchjournal.com Received: 12-12-2021 Accepted: 15-01-2022

Deepa Singh

Assistant Professor, Govt.

Nehru PG College, Burhar,

Madhya Pradesh, India

Shambhavi Sharma

Student, Govt. Nehru PG College, Burhar, Madhya Pradesh, India
Corresponding Author: Deepa Singh Assistant Professor, Govt. Nehru PG College, Burhar, Madhya Pradesh, India

\section{Analysis of financial performance of selected Banks in India: A comparative study on public sector banks and private sector banks}

\section{Deepa Singh and Shambhavi Sharma}

DOI: https://doi.org/10.22271/allresearch.2022.v8.i2f.9477

\begin{abstract}
Banking system is the backbone of every country. The functions of banks mainly revolve around accepting deposits and lending which has widened with ancillary functions in the present period of time. The financial performance of banks is the sum total of the activities for managing banking transactions. The performance of the banks is reflected through the Profit \& loss Account and Balance sheet which is prepared annually. The study analyses the financial performance of public sector banks and private sector banks by calculating and comparing various ratios of selected banks. The objectives of the study are firstly to study the financial performance of public sector banks and private sector banks in India and to compare the performances of selected public sector banks and private sector banks. Three public sector banks (Bank of Baroda, State bank of India and Punjab National Bank) and three private sector banks (HDFC bank, ICICI bank, and Axis bank) of India have been selected for the study. This study covers the period of four years from 2016-17 to 2019-20.

The findings of the study depict that Private sector banks performed better in maintaining Capital Adequacy, managing non-Performing assets and making adequate provisions for bad loans, positive returns on equity, high returns on assets, high net interest margin by managing investments efficiently and maintaining adequate debt-equity ratio while public sector banks performed better in maintaining adequate credit- deposit ratio and current ratio. The overall financial performance of private sector banks had been comparatively better than the public sector banks during the period of the study.

The study excludes other banks such as foreign banks, cooperative banks, regional rural banks which also play an important role in Indian banking system. The study constraints on a limited period of four years and limited variables for analyzing the financial performance of selected public sector banks and Private sector banks.
\end{abstract}

Keywords: Assets, performance, mean, trend, public and private

\section{Introduction}

Banking system is the backbone of every country. The functions of banks mainly revolve around accepting deposits and lending which has widened with ancillary functions in the present period of time. The Indian banking system comprises public sector banks, private sector banks, foreign banks, Co-operative banks, Regional rural banks and organized sector banks such as Export-Import Bank of India (EXIM Bank), National Housing bank, Small Industries Development Bank of India (SIDBI) etc. The Reserve bank of India controls the operations of banks in India. The advancement of technology paved the way for the growth and development of banks in handling operations, ease of deposits and disbursement and transfer of funds.

The recent measures of the government for strengthening the banking system involves merger, amalgamation and consolidation of banks to revive poorly performing assets and to wipe off the burden of bad loans. The consolidation of State Bank of India (SBI) took place on $1^{\text {st }}$ April, 2017 combining its five associate banks and Bhartiya Mahila Bank to form a single entity. The State-run Bank of Baroda became India's second largest public sector bank after its merger with Dena and Vijaya Bank respectively effective from 1 April, 2019. The recent merger became effective from April 1, 2020 which includes the merger of ten public sector banks into four. 
It includes Allahabad Bank with Indian Bank, Oriental Bank of Commerce (OBC) and United Bank of India with Punjab National Bank (PNB), Syndicate Bank with Canara Bank, Corporation Bank and Andhra Bank with Union Bank of India.

The financial performance of banks is the sum total of the activities for managing banking transactions. The performance of the banks is reflected through the Profit \& loss Account and Balance sheet which is prepared annually. The study analyses the financial performance of public sector banks and private sector banks by calculating and comparing various ratios of selected banks.

\section{Review of Literature}

C. Goel et al. (2013) ${ }^{[7]}$ conducted a comprehensive study on the performance of selected public sector and private sector banks in India. Three public sector banks and three private sector banks were selected on the basis of their total assets from the year 2009 to 2012 . The data was analyzed by using ratio and coefficient correlation which revealed that SBI, PNB and BOB reported less profitability due to low net interest margin. The association between Capital adequacy ratio and deposits was good in ICICI bank. The credit deposit ratio was high in HDFC bank Axis bank reported high return on assets. So, it can be interpreted that the financial performance of private sector banks was better in comparison to public sector banks of India.

Bansal R. (2014) ${ }^{[4]}$ in the study a comparative analysis of the financial ratios of selected banks in India for the period 2011-2014. The study concluded that the Federal bank had an ideal current ratio among all the four selected banks. HDFC bank and Federal bank had fairly stable Asset turnover ratio by comparing the Profitability ratio, Activity turnover ratio, Assets turnover ratio, Leverage ratio and DuPont analysis which indicated the efficient utilization of resources and also indicated that these banks kept significantly high assets to meet the debt obligations. Among the four banks, Federal bank was most financially stable.

Gupta and Sundram (2015) [1] in the research work 'Comparative study of Public and private sector banks in India' highlighted the performance of three private sector banks and three public sector banks during 2009-10 to 201314. Among the three public sector banks the performance of Punjab National banks was better in comparison to Bank of Baroda and Central bank of India. The private sector banks were able to utilize resources such as Assets, investments and deposits more efficiently in comparison to selected Public sector banks.

S. Subalakshmi et al. (2018) ${ }^{[15]}$ analyzed the financial performance of SBI from 2009 to 2016. The overall performance of SBI for the selected period was progressive on the basis of profit and loss A/c, Balance sheet and ratio analysis. The study revealed that SBI was required to work upon increasing Credit deposit ratio, maintaining adequate equity multiplier ratio, decreasing expenses to raise profit margin and taking necessary steps to reduce Nonperforming assets.

Veena and Pragathi (2018) conducted a study on financial performance of Canara bank and Union bank of India from 2013- 2017. The Capital adequacy ratio and Gross Non performing asset had shown an increasing trend whereas Return on asset ratio, Return on Equity ratio and Earning per Share showed a decreasing trend. The study concluded that reducing operating expenses and Non-performing Assets would increase the profit and Earning per share henceforth of both the banks.

Taqi and Mustafa (2018) ${ }^{[12]}$ attempted to evaluate the performance of Punjab National bank and HDFC bank by employing different parameters. The results of the study revealed that Punjab National bank performed better in terms of financial efficiency, market expansion and marketing of new schemes. The Non- performing assets of HDFC increased during the study period. It was concluded that retaining talented workforce, improving customer service and risk management would help in raising profitability of both the banks.

Beevi S.H (2019) examined the financial performance of Public sector and private sector banks using CAMEL Model for the period 2010 to 2012. The public sector performed better in terms of Capital Adequacy, Management efficiency and Liquidity. The Non- performing assets of Public sector banks were increasing. The Asset quality management of private sector banks was better due to the precautionary measures they followed while lending loans and advances. By following the same policies, the Public sector banks would be able to raise the profitability.

Koley (2019) ${ }^{[11]}$ compared the financial performance of SBI and HDFC from 2013-14 to 2017-18 with the help of CAMEL model, Mean and t- test. The study indicated that HDFC performed better in terms of Asset quality, management efficiency, earning ability and liquidity. The Capital Adequacy ratio of both the banks was satisfactory as it outperforms the Basel norms. The Debt equity ratio of SBI was high which highlighted that it was exposed to more financial risk and HDFC had taken a safer side by providing a high margin of safety to its depositors.

Rani M. (2020) ${ }^{[14]}$ Studied the financial performance of selected Public sector banks on the basis of operating profitability from 2015-16 to 2017-18. The top ten Public sector banks were selected on the basis of market capitalization. The banks which performed better according to the net profit as percentage of total income were Indian bank, Punjab National bank and Bank of India. The banks which performed better according to Operating profit as percentage of Working capital were State Bank of India, Punjab national bank and Bank of Baroda. The performance of Central Bank of India was not positive in terms of operating profitability during the period of study

\section{Objectives of the study}

1. To study the financial performance of public sector banks and private sector banks in India

2. To compare the performances of selected public sector banks and private sector banks.

\section{Research Methodology Data Collection}

The data has been collected purely from secondary sources. The population of the study are public and private sector banks of India. The sample of the study constitutes three public sector banks (Bank of Baroda, State bank of India and Punjab National Bank) and three private sector banks (HDFC bank, ICICI bank, and Axis bank). The data has been collected from moneycontrol.com and further verified by annual reports of selected banks which is published by banks every year. 


\section{Period of Study}

This study covers the period of four years from 2016-17 to 2019-20.

\section{Data Analysis}

The data has been collected and tabulated in Excel. The statistical tool used for analysis of financial performance of banks is ratio analysis. The statistical techniques used for interpretation are mean, standard deviation and coefficient of variation.

\section{Limitation of Study}

The study is based upon secondary data which is collected from online sources. The financial performance of banks has been studied for a period of four years. The ten-year period data would give more realistic results. The study excludes other banks such as foreign banks, cooperative banks, regional rural banks which also play an important role in Indian banking system. The study constraints on limited variables only for analyzing the financial performance of selected public sector banks and Private sector banks. The non-financial information and mergers and consolidations of public sector banks during the study period have not been included in the study.

\section{Variables of the Study}

The following eight variables have been selected to analysis the financial performance of selected banks namely, a) Capital Adequacy Ratio, b) Credit Deposit Ratio, c) Current Ratio, d) Net NPA, e) Return on Equity Ratio, f) Return on Assets Ratio, g) Debt- equity Ratio, h) Net Interest margin ratio.

\section{Data Analysis and Interpretation}

Ratio analysis is used as a tool in order to compare the financial performance of banks. Ratio analysis gives a glimpse of overall financial performance of banks. It helps the various stakeholders in assessing the current as well as future situation of banks.

These ratios have been employed to analyze and compare the financial performance of public sector banks and private sector banks-

\section{A. Capital Adequacy ratio}

The capital adequacy ratio (CAR) also known as capital to risk-weighted assets ratio measures a bank's financial strength by using its capital and assets. Generally, a bank with a high capital adequacy ratio is considered safe and likely to meet its financial obligations.

Capital Adequacy Ratio = $($ Tier I Capital + Tier II Capital $) /$ Risk-Weighted Assets

Table 5.1: Capital adequacy ratio of selected Banks

\begin{tabular}{|c|c|c|c|c|c|c|c|c|}
\hline & \multicolumn{4}{|c|}{ Public Sector Banks } & \multicolumn{4}{c|}{ Private sector banks } \\
\hline Year & BOB & SBI & PNB & Average & HDFC & ICICI & AXIS & Average \\
\hline 2017 & 11.55 & 13.1 & 11.58 & 12.07 & 15.5 & 10.3 & 14.95 & 13.58 \\
\hline 2018 & 13.52 & 12.6 & 10.52 & 12.21 & 14.8 & 18.42 & 16.57 & 16.59 \\
\hline 2019 & 13.45 & 12.72 & 12.63 & 12.93 & 17.1 & 15.09 & 15.84 & 16.01 \\
\hline 2020 & 13.3 & 13.06 & 14.14 & 13.5 & 18.9 & 16.11 & 17.53 & 17.51 \\
\hline Mean & 12.95 & 12.87 & 12.21 & 12.69 & 16.57 & 14.98 & 16.22 & 15.92 \\
\hline Standard deviation & 0.94 & 0.24 & 1.54 & 0.9 & 1.82 & 3.41 & 1.09 & 2.1 \\
\hline Variance & 0.88 & 0.06 & 2.38 & 1.66 & 3.32 & 11.67 & 1.19 & 5.39 \\
\hline
\end{tabular}

Source: moneycontrol.com

Table1 exhibits that bank wise average, standard deviation and coefficient of variation of Capital Adequacy ratio of selected banks. The capital Adequacy ratio of all the banks exceeds the benchmark but at the same time shows decreasing trend over the period of study. BOB has the highest mean i.e., 12.95 and PNB has lowest mean i.e., 12.21 among the selected Public Sector banks. The standard deviation of capital Adequacy ratio of SBI is 0.24 which is more consistent with lower coefficient of variation i.e., 0.06 as compared to BOB and PNB. On the other hand, in Private sector banks, HDFC bank has highest mean i.e., 16.57 and ICICI bank has lowest mean i.e., 14.98 among the selected Private sector banks. The Standard deviation of capital adequacy ratio of AXIS bank is 1.09 which is more consistent with low coefficient of variation of 1.19 . The analysis shows that the Capital adequacy ratio of private sector banks is higher indicating efficient management of capital and assets and fulfilment of financial obligations in the coming years.

\section{B. Credit Deposit Ratio}

This ratio shows how much deposits are utilized for lending activities. High credit deposit ratio indicates that banks rely more on deposits for lending. The Credit Deposit Ratio is the proportion of loan created by a bank from the deposits received.

Credit Deposit ratio $=$ Advances $/$ Total Deposits

Table 5.2: Credit Deposit ratio of selected Banks

\begin{tabular}{|c|c|c|c|c|c|c|c|c|}
\hline & \multicolumn{4}{|c|}{ Public Sector Banks } & \multicolumn{4}{c|}{ Private sector banks } \\
\hline Year & BOB & SBI & PNB & Average & HDFC & ICICI & AXIS & Average \\
\hline 2017 & 71.86 & 72.3 & 67.47 & 70.54 & 86.16 & 94.73 & 90.03 & 90.3 \\
\hline 2018 & 72.28 & 72.47 & 67.54 & 70.76 & 83.46 & 91.34 & 96.92 & 90.57 \\
\hline 2019 & 73.4 & 73.94 & 67.79 & 71.71 & 88.76 & 89.85 & 90.21 & 89.42 \\
\hline 2020 & 72.95 & 74.04 & 67.04 & 71.34 & 86.59 & 88.74 & 89.27 & 88.13 \\
\hline Mean & 72.62 & 73.18 & 67.46 & 71.08 & 86.24 & 91.16 & 91.6 & 89.66 \\
\hline Standard deviation & 0.68 & 0.93 & 0.31 & 0.64 & 2.17 & 2.6 & 3.56 & 2.77 \\
\hline Variance & 0.47 & 0.86 & 0.09 & 0.47 & 4.73 & 6.78 & 0.28 & 3.93 \\
\hline
\end{tabular}

Source: moneycontrol.com 
Table 2 exhibits that bank wise average, standard deviation and coefficient of variation of credit to deposit ratio of selected banks. The table shows the year wise Credit to deposit ratio has fluctuated over the period of study. BOB and PNB have shown decreasing trends over the period of study. SBI has the highest mean i.e.,73.18 and PNB has lowest mean i.e., 67.46 among the selected Public Sector Banks. The standard deviation of credit deposit ratio of PNB is 0.31 which is more consistent and lower coefficient of variation i.e., 0.09 as compared to BOB and SBI. On the other hand, Private sector banks have also shown fluctuating trends over the period of study. AXIS bank has highest mean i.e., 91.60 and HDFC bank has the lowest mean i.e., 86.24 credit to deposit ratio among the selected Private sector banks. The Standard deviation of credit deposit ratio of HDFC bank is 2.17 which is more consistent but the coefficient of variation of AXIS bank is lower i.e., 0.28 as compared to HDFC bank and ICICI bank. The above table depicts that Credit deposit ratio of Private sector banks is very high implying shortage of liquid assets with the banks. It has been found that public sector banks have got a better position when compared to private sector banks in terms of credit to deposit ratio during the period of study.

\section{Current Ratio}

Current ratio measures the firm's capability to meet its short-term obligations. The current ratio is calculated by dividing current assets by current liabilities. The higher the result, the stronger the financial position of a company. Current Ratio $=$ Current Assets $/$ Current Liabilities

Table 5.3: Current ratio of selected banks

\begin{tabular}{|c|c|c|c|c|c|c|c|c|}
\hline & \multicolumn{4}{|c|}{ Public Sector Banks } & \multicolumn{4}{c|}{ Private sector banks } \\
\hline Year & BOB & SBI & PNB & Average & HDFC & ICICI & AXIS & Average \\
\hline 2017 & 1.16 & 0.99 & 1.22 & 1.29 & 0.74 & 1.58 & 1.73 & 1.35 \\
\hline 2018 & 1.37 & 1.36 & 1.38 & 1.37 & 0.8 & 2.16 & 1.92 & 1.62 \\
\hline 2019 & 1.4 & 1.83 & 2.23 & 1.82 & 0.89 & 2.38 & 1.81 & 1.69 \\
\hline 2020 & 1.33 & 1.78 & 2.47 & 1.86 & 0.8 & 1.38 & 2.03 & 1.4 \\
\hline Mean & 1.31 & 1.49 & 1.82 & 1.54 & 0.8 & 1.87 & 1.87 & 1.51 \\
\hline Standard deviation & 0.1 & 0.39 & 0.61 & 0.36 & 0.06 & 0.47 & 0.13 & 0.22 \\
\hline Variance & 0.011 & 0.155 & 0.381 & 0.182 & 0.003 & 0.222 & 0.017 & 0.08 \\
\hline
\end{tabular}

Source: moneycontrol.com

Table 3 exhibits that bank wise average, standard deviation and coefficient of variation of Current ratio of selected banks. The table shows that the year wise current ratio has fluctuated over the period of study. The PNB has the highest mean i.e., 1.82 and BOB has lowest mean i.e., 1.31 among the selected Public Sector Banks. The Standard deviation of Current ratio of $\mathrm{BOB}$ is 0.1 which is more consistent and lower coefficient of variation i.e., 0.011 as compared to SBI and PNB. The average current ratio of public sector banks was highest in the year 2020. On the other hand, in Private sector banks, ICICI and AXIS bank have highest mean i.e., 1.87 and HDFC bank has lowest mean i.e., 0.80 current ratio among the selected Private sector banks. The Standard deviation of current assets of HDFC bank is 0.06 which is more consistent and lower coefficient of variation i.e., 0.003 of as compared to AXIS bank and ICICI bank. The mean of current ratio of public sector banks is slightly higher than the mean of private sector banks implying a better shortterm arrangement of funds. The performance of all the banks is satisfactory except HDFC bank as the ratio had been less than one in every year during the period of study.

\section{Net NPA}

Non-Performing assets (NPA) is any advance or loan that is overdue for more than ninety days. Net Non-Performing assets is the amount that remains after deducting provision for uncertain and unpaid debts from the total sum of defaulted loans.

Net NPA $=($ Gross NPA $)-($ Provision for unpaid debts $) /$ Gross Advances

Table 5.4: Net NPA of Selected banks

\begin{tabular}{|c|c|c|c|c|c|c|c|c|}
\hline & \multicolumn{4}{|c|}{ Public Sector Banks } & \multicolumn{4}{c|}{ Private sector banks } \\
\hline Year & BOB & SBI & PNB & Average & HDFC & ICICI & AXIS & Average \\
\hline 2017 & 4.72 & 3.71 & 7.81 & 5.41 & 0.33 & 4.89 & 2.11 & 2.44 \\
\hline 2018 & 5.49 & 5.73 & 11.24 & 7.48 & 0.4 & 4.77 & 3.4 & 2.85 \\
\hline 2019 & 3.33 & 3.01 & 6.56 & 4.3 & 0.39 & 2.06 & 2.06 & 1.5 \\
\hline 2020 & 3.13 & 2.23 & 5.78 & 3.71 & 0.36 & 1.41 & 1.56 & 1.11 \\
\hline Mean & 4.16 & 3.67 & 7.8 & 5.21 & 0.37 & 3.28 & 2.28 & 1.97 \\
\hline Standard deviation & 1.13 & 1.5 & 2.41 & 1.68 & 0.03 & 1.8 & 0.78 & 0.87 \\
\hline Variance & 1.27 & 2.25 & 5.81 & 3.11 & 0.001 & 3.26 & 0.61 & 1.29 \\
\hline
\end{tabular}

Source: moneycontrol.com

Table 4 exhibits that bank wise average, standard deviation and coefficient of variation of Net NPA of selected banks. The table shows that year wise Net NPA has fluctuated but showed a decreasing trend over the period of study which is a positive signal. The PNB has the highest mean i.e.,7.8 and SBI has lowest mean i.e., 3.67 among the selected Public Sector Banks. The Standard deviation of Net NPA of BOB is 1.13 which is more consistent and lower coefficient of variation i.e., 1.27 as compared to SBI and PNB. The average Net NPA of selected public sector banks was highest in the year 2018. On the other hand, Private sector banks such as, ICICI bank and Axis bank have shown decreasing trend but HDFC maintained the ratio that equates to less than one in every year during the period of study. ICICI bank has the highest mean i.e., 3.28 and HDFC bank has lowest mean i.e., 0.37 among the selected Private sector banks. The Standard deviation of Net NPA of HDFC bank is 0.03 which is more consistent and lower coefficient of 
variation i.e., 0.001 of as compared to AXIS bank and ICICI bank. The private sector banks performed better in terms of managing non-Performing assets and making adequate provisions for bad loans in comparison to public sector banks during the period of study.

\section{E. Return on Equity Ratio}

Table 5.5: Return on Equity ratio of selected banks

\begin{tabular}{|c|c|c|c|c|c|c|c|c|}
\hline & \multicolumn{4}{|c|}{ Public Sector Banks } & \multicolumn{4}{c|}{ Private sector banks } \\
\hline Year & BOB & SBI & PNB & Average & HDFC & ICICI & AXIS & Average \\
\hline 2017 & 3.43 & 6.69 & 3.47 & 4.53 & 17.26 & 10.11 & 6.59 & 11.32 \\
\hline 2018 & -5.6 & -3.37 & -32.8 & -13.92 & 16.45 & 6.63 & 0.43 & 7.83 \\
\hline 2019 & 0.94 & 0.39 & -24 & -7.55 & 14.12 & 3.19 & 7.01 & 8.1 \\
\hline 2020 & 0.76 & 6.95 & 0.58 & 2.76 & 15.35 & 6.99 & 1.91 & 8.08 \\
\hline Mean & -0.11 & 2.66 & -13.1 & -3.51 & 15.79 & 6.73 & 3.98 & 8.83 \\
\hline Standard deviation & 3.85 & 5.03 & 17.96 & 8.88 & 1.36 & 2.83 & 3.31 & 2.5 \\
\hline Variance & 14.84 & 25.38 & 322.8 & 121 & 1.85 & 8.01 & 10.9 & 6.92 \\
\hline
\end{tabular}

Source: moneycontrol.com

Table 5 exhibits that bank wise average, standard deviation and coefficient of variation of Return on Equity ratio of selected banks. The table shows that the year wise Return on Equity ratio has fluctuated and majorly showed a negative trend over the period of study. The SBI has the positive mean i.e., 2.66 and the mean of BOB and PNB is -0.11 and 13.1 respectively. The Standard deviation of Net NPA of $\mathrm{BOB}$ is 3.85 which is more consistent and lower coefficient of variation i.e., 14.84 as compared to SBI and PNB. On the other hand, Private sector banks have shown a positive trend throughout the period of study. HDFC bank has highest mean i.e., 15.79 and AXIS bank has lowest mean i.e., 3.98 among the selected Private sector banks. The Standard deviation of Return on Equity ratio of HDFC bank is 1.36 which is more consistent and lower coefficient of variation i.e., 1.85 as compared to AXIS bank and ICICI bank. The
This ratio indicates the net income that banks earn for equity shareholders after deducting taxes from total earnings. It indicates the proficiency of banks to generate profits from shareholders investments. This ratio acts as a fundamental for the present as well the potential investors of the banks. Return on Equity ratio = Net Income/ Shareholders fund

Table 5.6: Return on Assets ratio of selected banks

\begin{tabular}{|c|c|c|c|c|c|c|c|c|}
\hline & \multicolumn{4}{|c|}{ Public Sector Banks } & \multicolumn{4}{c|}{ Private sector banks } \\
\hline Year & BOB & SBI & PNB & Average & HDFC & ICICI & AXIS & Average \\
\hline 2017 & 0.19 & 0.38 & 0.18 & 0.25 & 1.52 & 0.38 & 0.61 & 0.84 \\
\hline 2018 & -0.33 & 0.02 & -1.6 & -0.63 & 1.64 & 0.02 & 0.03 & 0.56 \\
\hline 2019 & 0.05 & -0.19 & -1.28 & -0.47 & 1.69 & -0.19 & 0.58 & 0.69 \\
\hline 2020 & 0.04 & 0.41 & 0.04 & 0.16 & 1.71 & 0.41 & 0.17 & 0.76 \\
\hline Mean & -0.01 & 0.155 & -0.665 & -0.17 & 1.64 & 0.15 & 0.34 & 0.71 \\
\hline Standard deviation & 0.22 & 0.29 & 0.9 & 0.47 & 0.08 & 0.29 & 0.29 & 0.22 \\
\hline Variance & 0.049 & 0.0843 & 0.821 & 0.318 & 0.007 & 0.084 & 0.085 & 0.058 \\
\hline
\end{tabular}

Source: moneycontrol.com

public sector banks had not matched the returns on equity given by private sector banks in any year during the period of study. Considering the overall performance, the negative returns and variance of PNB went very high during the period of study and HDFC bank performed remarkably as the returns are approximately thrice than the positive returns of other selected banks.

\section{F. Return on Assets Ratio}

Return of Assets is the ratio which measures the annual net income to the total assets of the company during a financial year. The return on assets shows how efficiently a company can convert assets into net income or profits. Higher return on assets ratio depicts the efficiency of banks in managing assets.

Return on Assets ratio $=$ Net Income/ Average total assets that bank wise average, standard deviation Table 6 exhibits that bank wise average, standard deviation
and coefficient of variation of return on assets of selected banks. The table shows the year wise return on assets ratio had fluctuated over the period of study. All public sector banks had shown a decreasing and negative trend. SBI has highest mean i.e., 0.15 and PNB has lowest mean i.e., -0.66 among the selected public sector banks. The Standard deviation of returns on assets ratio of BOB bank is 0.22 which is more consistent and lower coefficient of variation i.e., 0.049 as compared to SBI and PNB. On the other hand, Private sector banks have also shown fluctuating and decreasing trends except HDFC bank over the period of study. HDFC bank has highest average i.e., 1.64 and ICICI bank has lowest average i.e., 0.15 among the selected Private sector banks. The Standard deviation of return on assets ratio of HDFC bank is 0.08 which is more consistent and lower coefficient of variation i.e., 0.0007 as compared to ICICI and Axis bank. It reveals that private sector banks have got a better position when compared to public sector banks in terms of return on assets ratio.

\section{G. Debt-Equity Ratio}

Debt Equity ratio calculates the proportion of total debt against total shareholders' equity. It also indicates the weightage of debt and equity for financing operations of the bank. The debt - equity ratios less than one signify less risky banking operations. The ratio shows the use of debt financing for every rupee one of equity financing.

Debt to Equity ratio = Total long-term debt/ Shareholders equity 
Table 5.7: Debt Equity ratio of selected banks

\begin{tabular}{|c|c|c|c|c|c|c|c|c|}
\hline & \multicolumn{4}{|c|}{ Public Sector Banks } & \multicolumn{4}{c|}{ Private sector banks } \\
\hline Year & BOB & SBI & PNB & Average & HDFC & ICICI & AXIS & Average \\
\hline 2017 & 15.69 & 15.08 & 17.39 & 16.05 & 7.56 & 6.58 & 9.31 & 7.81 \\
\hline 2018 & 15.07 & 15.79 & 18.8 & 16.55 & 6.97 & 7.28 & 9.48 & 7.91 \\
\hline 2019 & 15.37 & 16.89 & 17.36 & 16.54 & 8.58 & 7.77 & 10.52 & 8.95 \\
\hline 2020 & 14.46 & 17.08 & 13.09 & 14.87 & 8.02 & 8.24 & 9.28 & 8.51 \\
\hline Mean & 15.14 & 16.21 & 16.66 & 16.00 & 7.78 & 7.46 & 9.64 & 8.29 \\
\hline Standard deviation & 0.52 & 0.94 & 2.47 & 1.31 & 0.68 & 0.7 & 0.58 & 0.65 \\
\hline Variance & 0.27 & 0.89 & 6.11 & 2.42 & 0.46 & 0.5 & 0.34 & 0.43 \\
\hline
\end{tabular}

Source: moneycontrol.com

Table 7 exhibits that bank wise average, standard deviation and coefficient of variation of Debt-equity ratio of selected banks. All public sector banks had shown an increasing as well as decreasing trend during the period of study. PNB has the highest mean i.e.,16.66 and BOB has the lowest mean i.e., 15.14 among the selected public sector banks. The Standard deviation of debt-equity ratio of BOB bank is 0.52 which is more consistent and lower coefficient of variation i.e., 0.27 as compared to SBI and PNB. On the other hand, Private sector banks, ICICI bank and Axis bank have shown fluctuating trends over the period of study. AXIS bank has highest mean i.e., 9.64 and ICICI bank has lowest mean i.e., 7.46 among the selected Private sector banks. The Standard deviation of debt-equity ratio of Axis bank is 0.58 which is more consistent with lower coefficient of variation i.e., 0.34 as compared to HDFC bank and ICICI bank. The average debt- equity ratio of public sector banks has been more than private sector banks during the period of study implying higher risk to the creditors and investors. The public sector banks had been generating more funds through external sources.

\section{H. Net Interest margin ratio}

The net interest margin of banks is calculated by deducting total interest paid out of total interest generated divided by total assets. A positive ratio shows investments are efficiently managed while a negative ratio shows inefficiency because total interest paid was higher than total revenues earned on the investment.

The Net Interest Margin is calculated by using the formula, Net Interest margin ratio = Interest Earned-Interest paid / Total assets

Table 5.8: Net Interest Margin ratio of selected banks

\begin{tabular}{|c|c|c|c|c|c|c|c|c|}
\hline & \multicolumn{4}{|c|}{ Public Sector Banks } & \multicolumn{4}{c|}{ Private sector banks } \\
\hline Year & BOB & SBI & PNB & Average & HDFC & ICICI & AXIS & Average \\
\hline 2017 & 1.94 & 2.28 & 2.08 & 2.1 & 3.76 & 2.61 & 2.69 & 3.02 \\
\hline 2018 & 2.15 & 2.16 & 1.94 & 2.08 & 3.87 & 2.8 & 2.17 & 2.94 \\
\hline 2019 & 2.36 & 2.4 & 2.21 & 2.32 & 3.67 & 3.02 & 2.75 & 3.14 \\
\hline 2020 & 2.37 & 2.48 & 2.09 & 2.31 & 3.71 & 3.16 & 2.93 & 3.26 \\
\hline Mean & 2.2 & 2.33 & 2.08 & 2.2 & 3.75 & 2.89 & 2.63 & 3.09 \\
\hline Standard deviation & 0.2 & 0.14 & 0.11 & 0.15 & 0.08 & 0.24 & 0.32 & 0.21 \\
\hline Variance & 0.04 & 0.019 & 0.012 & 0.023 & 0.007 & 0.05 & 0.106 & 0.054 \\
\hline
\end{tabular}

Source: moneycontrol.com

Table 8 reveals that bank wise average, standard deviation and coefficient of variation of Net interest margin of selected banks. The table shows that the year wise net interest margin ratio of public sector banks had fluctuated over the period of study. BOB and SBI have shown an increasing trend. SBI has the highest mean i.e., 2.33 and PNB has the lowest mean i.e., 2.08 among the selected public sector banks. The Standard deviation of net interest margin of PNB is 0.11 which is more consistent with low coefficient of variation i.e., 0.012 as compared to BOB and SBI. On the other hand, among the selected private sector banks, ICICI bank and AXIS bank have shown increasing trend. HDFC bank has the highest average i.e., 3.75 and Axis bank has the lowest average i.e., 2.63. The Standard deviation of net interest margin of HDFC bank is 0.08 which is more consistent with low coefficient of variation i.e., 0.007 as compared to ICICI bank and Axis bank. The mean of net interest margin ratio of private sector banks is higher than the mean of net interest margin ratio of public sector banks during the period of study. It implies better management of assets by private sector banks.

\section{Findings}

- The mean of capital adequacy ratio of selected private sector banks is $15.92 \%$ which is higher than the mean of capital adequacy ratio of selected public sector banks which is $12.69 \%$. The private sector banks are in a better position to fulfill financial obligations.

- The mean of credit deposit ratio of private sector banks is very high i.e., $89.66 \%$ implying shortage of liquid assets with the banks. It has been found that public sector banks have got a better position i.e., 71.08\% when compared to private sector banks in terms of credit to deposit ratio during the period of study.

- The mean of current ratio of public sector banks is 1.54 times which is slightly higher than the mean of private sector banks i.e., 1.51 times implying a better shortterm arrangement of funds. The performance of all the banks is satisfactory except HDFC bank as the ratio had been less than one in every year during the period of study.

- The mean Net Non-performing assets (NPA) ratio of selected public sector banks is 5.21 which is higher than the average Net Non-performing assets (NPA) of selected Public sector banks which is 1.97 . The private sector banks performed better in terms of managing Non-Performing assets and making adequate provisions for bad loans in comparison to public sector banks during the period of study. 
- The public sector banks had not matched the returns on equity given by private sector banks in any year during the period of study. Considering the overall performance, the negative returns and variance of PNB went very high during the period of study and HDFC bank performed remarkably as the returns are approximately thrice than the positive returns of other selected banks.

- The mean of return on assets ratio of public sector banks is -0.17 and the mean of return on assets ratio of private sector banks is 0.71 . It reveals that private sector banks have got a better position when compared to public sector banks in terms of return on assets ratio during the period of study.

- The mean of debt- equity ratio of public sector banks has been higher than private sector banks during the period of study implying higher risk to the creditors and investors. It also indicates that public sector banks had been generating more funds through external sources rather than managing internal sources efficiently.

- The mean of net interest margin ratio of private sector banks is higher than the mean of net interest margin ratio of public sector banks during the period of study. It implies better management of assets by private sector banks.

\section{Conclusion}

Private sector banks performed better in maintaining Capital Adequacy, managing non-performing assets and making adequate provisions for bad loans, positive returns on equity, high returns on assets, high net interest margin by managing investments efficiently and maintaining adequate debt-equity ratio while public sector banks performed better in maintaining adequate credit- deposit ratio and current ratio. The overall financial performance of private sector banks had been comparatively better than the public sector banks during the period of the study. The provisions of private sectors are more viable and effective as these banks have outperformed in financial terms. The significant step of merger and consolidation of public sector banks would help the banks in reviving their financial position and curtailing the Non-performing assets which is the biggest hindrance in the success of public sector banks.

\section{References}

1. Ashish Gupta VS. Comparative study of public and private sector banks: An empirical analysis. International Journal of Applied Research. 2015;1(12):895-901. Retrieved from www.allresearchjournal.com

2. Axis Bank Ltd. 2020. Retrieved April 28, 2021, from moneycontrol.com:

https://www.moneycontrol.com/financials/axisbank/rati osVI/AB 16

3. Bank of Baroda. 2020. Retrieved April 25, 2021, from moneycontrol.com:

https://www.moneycontrol.com/financials/bankofbarod a/ratiosVI/bob

4. Bansal R. A Comparative Analysis of the Financial Ratios of Selected Banks in the India for the period of 2011-2014. Research Journal of Finance and Accounting. 2014;5(19):153-167. Retrieved from http://www.iiste.org/
5. Beers B. Financial Ratio. 2019. Retrieved from Investopedia:

https://www.investopedia.com/ask/answers/040115/wh at-does-it-mean-when-company-has-high-capitaladequacy-ratio.asp

6. Beevi DS. Financial Performance of Public and private sector banks in India using Camel Model. International Journal of Research and Analytical Reviews. 2018;5(4):430-434.

7. Cheenu Goel CB. A Comparative Study on the Performance of Selected Public Sector and Private Sector Banks in India. Journal of Business Management \& Social Sciences Research. 2013;2(7):46-56. Retrieved from http://www.borjournals.com/

8. HDFC Bank Ltd. 2020. Retrieved April 28, 2021, from moneycontrol.com:

https://www.moneycontrol.com/financials/hdfcbank/rati osVI/hdf01/2

9. ICICI Bank. 2020. Retrieved April 28, 2021, from moneycontrol.com:

https://www.moneycontrol.com/stocks/company_info/fi nancial_ratios.php?sc_did=ICI02

10. KP, DV. A Comparative Study of Financial Performance of Canara Bank and Union Bank of India. IJEMR. 2018;8(6).

11. Koley J. Analysis of Financial Position and Performance of Public and Private Sector Banks in India: A Comparative Study on SBI and HDFC Bank. Nsou-Open Journal. 2019;2(1).

12. Mustafa DM. Financial Analysis of Public and Private Sector Banks of India: A Comparative study on Punjab National Bank and HDFC Bank. International Academic Journal of Business Management. 2018;5(1):26-47. Retrieved from http://www.iaiest.com/

13. Punjab National Bank. 2020. Retrieved april 25, 2021, from moneycontrol.com: https://www.moneycontrol.com/financials/punjabnation albank/ratiosVI/PNB05

14. Rani M. An Analysis of financial performance of Selected public sector banks in India. Journal of critical reviews. 2020;7(16):1455-1458.

15. Subalakshmi S, SG. Financial Ratio analysis of SBI (2009-2016). ICTACT Journal on management studies, 2018;4(1):698-704. doi:10.21917/ijms.2018.0095

16. State bank of India. 2020. Retrieved April 25, 2021, from moneycontrol.com: https://www.moneycontrol.com/financials/statebankofi ndia/ratiosVI/SBI 